\title{
University-industry collaboration and firm innovation: an empirical study of the biopharmaceutical industry
}

\author{
Mingyu Tian ${ }^{1} \cdot$ Yiwei Su${ }^{1}\left[\right.$ ? Zhong Yang ${ }^{1}$
}

Accepted: 16 August 2021 / Published online: 25 August 2021

(C) The Author(s), under exclusive licence to Springer Science+Business Media, LLC, part of Springer Nature 2021

\begin{abstract}
Existing research has shown that university-industry collaboration (UIC) helps a firm achieve superior innovation outcomes. However, little is known about how UIC affects firm innovation when considering interfirm alliances. In this paper, we examine the influence of UIC on firm innovation performance by considering the interfirm alliance network. Based on a panel of 285 biopharmaceutical firms across the world over a thirty-year period from 1985 to 2014, we find that UIC enhances firm innovation performance. More alliances with other firms hinder the positive effect of UIC on firm innovation, whereas technological diversity strengthens the influence of UIC. Theoretical and practical implications of the results are discussed.
\end{abstract}

Keywords University-industry collaboration $\cdot$ Innovation performance $\cdot$ Strategic alliances $\cdot$ Alliance network $\cdot$ Interorganizational relationships

\section{Introduction}

Interorganizational relationships play a crucial role on firm performance due to the access to external knowledge from collaboration partners, especially for firms in knowledge-intensive industries (Powell et al., 1996). For example, research has shown that biotech firms benefit from interorganizational associations of faster time to and greater valuations at IPO (Stuart et al., 1999). Researchers are dedicated to exploring the influence of interfirm relationships on firm innovation and there are fruitful empirical findings in this field (Ahuja, 2000; Burt, 1992; Coleman, 1990; Kumar \& Zaheer, 2019; Phelps, 2010; Stuart, 2000). In addition to interfirm relationships, firms may benefit from relationships with universities as well.

Collaboration between R\&D of firms and research of universities has a long history (Mowery et al., 2002). According to surveys of the Association of University Technology Managers, patent licensing in universities increased dramatically since the Bayh-Dole Act of 1980 in the U.S. Academic entrepreneurship of U.S. universities also expanded quickly, bringing valuable academic outputs to the industry. Knowledge spillovers from

Yiwei Su

suyw@smail.nju.edu.cn

1 School of Business, Nanjing University, Nanjing 210093, China 
University-Industry Collaboration (UIC) such as licensing and entrepreneurship of universities promote innovation in high technology industries (Anselin et al., 1997). In addition, research partnerships and research services between universities and firms also play an important role on firm innovation (Perkmann \& Walsh, 2007).

Several studies have examined the relationship between UIC and firm innovation and most of the results support the positive influence of UIC on innovation (Baba et al., 2009; Biedenbach et al., 2018; Kobarg et al., 2018). However, what remains unclear is how UIC influences firm innovation when considering interfirm alliances. As two distinct but important types of alliances, both UIC and interfirm alliances are crucial for firms. However, diseconomies of scale push them to consider the optimal combination of UIC and interfirm alliances. Moreover, it may cause the problem of estimation bias if we explore the impact of UIC on firm innovation without controlling for interfirm alliances. Therefore, it is necessary to reconsider the influence of UIC on firm innovation performance by taking interfirm alliances into account.

We fill in the blank by exploring the impact of UIC on firm innovation performance with the consideration of the interfirm alliance network and studying contingencies that may influence the strength of the relationship. Specifically, we investigate the following questions: How does UIC influence firm innovation performance when concerning the interfirm alliance network? How do a firm's alliances with other firms and technological diversity of the firm moderate the influence of UIC on firm innovation?

In this paper, we theorize about and test the consequences of UIC on firm innovation performance. We use a panel of 285 firms in the biopharmaceutical industry over a thirtyyear period from 1985 to 2014 to empirically test our hypotheses. We apply a Poisson fixedeffects quasi-maximum likelihood estimator, based on the fact that our dependent variable is a citation-weighted patent count, to control for unobserved time-invariant heterogeneity. We control for the alliance network of the focal firm to remove the influence of interfirm alliances on its innovation performance. Our results indicate that UIC positively influences firm innovation. The positive relationship is weaker if the focal firm spans its alliances with other firms, and it is stronger if the technological diversity of the focal firm is higher.

This study stands to make three main contributions. First, we supplement the UIC literature by suggesting that prior research exploring the effect of UIC on firm innovation neglected the necessity of controlling for the impact of the interfirm alliance network, and it may cause bias of the estimation. Second, we contribute to research on interorganizational relationships by elaborating and testing the relationship between UIC and innovation. To the best of our knowledge, this is the first paper that is aware of the negative interaction between UIC and interfirm alliances on firm innovation performance. Finally, the results of our study have managerial implications for firms. Specifically, we suggest that firms should be careful about the trade-off between collaboration with universities and with firms. Additionally, firms should gauge the effect of technological diversity on innovation by taking UIC into consideration.

\section{Theory and hypotheses}

\subsection{University-industry collaboration and firm innovation}

To understand how UIC influences firm innovation, we build on search and recombination perspective. Firms not only search for knowledge components but also seek the way to 
combine them to achieve innovation (Arthur, 2007; Fleming, 2001). From this perspective, it is crucial to search for knowledge prepared for recombination. Beyond internal knowledge, firms need paths to acquire external knowledge, integrating it to enhance existing knowledge stock (Hamel, 1991). In this sense, UIC could be viewed as a path searching for external knowledge from academic research.

Interorganizational collaboration is crucial for firm innovation (Baden-Fuller \& Grant, 2004; Lane \& Lubatkin, 1998; Powell et al., 1996). Firms not only benefit from the collaboration for information and knowledge (Balachandran \& Hernandez, 2018; Smith-Doerr et al., 1999; Soh, 2003), but also receive knowledge spillovers from its partners because partners share relevant knowledge and information (Demirkan \& Demirkan, 2012). Consequently, interorganizational collaboration is an effective path of searching for knowledge prepared for recombination. Moreover, collaboration reduces costs and risks of innovation (Ahuja, 2000), as it brings a broader knowledge set and lower expenses for each partner.

In addition to the aforementioned benefits of interorganizational collaboration, firms could further benefit from UIC because of the unique property of academic research. Rather than R\&D of firms emphasizing economic value, academic research mainly focuses on basic research that is more interested in fundamental-level problems. But it does not mean that university researchers are not motivated by practical problems from reality and actually it is the central role of academic research in many fields (Rosenberg \& Nelson, 1994). For instance, many universities around the world focus on the development COVID19 vaccine nowadays, trying to defeat COVID-19 and save hundreds of thousands of lives. Academic research also continues to pay attention to artificial intelligence (AI), and relevant findings are widely applied in various fields such as health care, finance, and autonomous driving. High-quality academic research is attractive to industries seeking novel knowledge for innovation. Therefore, the industry has a strong motivation towards the relationships with universities (Ankrah \& Omar, 2015), to benefit from knowledge spillovers of universities, especially under today's fierce competition.

We contend that the main reason firms choose to collaborate with universities is to search for diverse knowledge. Diversity promotes knowledge recombination, increasing the likelihood of generating innovative ideas (Fleming, 2001; Henderson \& Clark, 1990; Utterback, 1971). Various kinds of diversity, such as ethnic diversity (Nathan, 2015), employee diversity (Østergaard et al., 2011), R\&D team diversity (Reagans et al., 2004), and technological diversity (Suzuki \& Kodama, 2004) are considered to be relevant to creativity and innovation. When referring to firms, Burt (1992) emphasizes the role of non-redundant information on firm performance, whereas Phelps (2010) indicates that the technological diversity of a firm's partner increases firm innovation. In addition, our opinion is consistent with social resource theory (Lin, 1982; March \& Wesoowski, 1986), stressing the importance of necessary resources a firm could be accessed through its alliances to fulfill its research needs.

In this view, UIC could be viewed as a path for diverse knowledge for the focal firm. Basic research of universities is a special source of knowledge that is distinct from the knowledge of the firm. Therefore, if a firm chooses to collaborate with universities, it could acquire diverse knowledge from high-quality research, contributing to the recombination and thus increasing the likelihood of innovation. Hence, collaboration with universities is a strategy that firms could employ to respond to the increasing uncertainty of rapid technology development (Oliver, 1990). Additionally, UIC is consistent with the government policy encouraging this kind of collaboration and firms may benefit further from government programs of subsidies and tax deduction (Howells et al., 1998). 
Research also emphasizes the problem of different institutional cultures that may impede the success of UIC. The basis of academic research is to freely explore knowledge. As Merton (1973) claims, communalism, universalism, disinterestedness, and organized skepticism are the norms of science. But the aim of the industry is to commercialize and economically benefit from knowledge to gain a competitive advantage (Teece, 1986). Cultural differences between universities and firms might be detrimental to their collaboration (Gassol, 2007). Trust is considered to be important to UIC (Bellini et al., 2019), since universities and firms share sensitive information and knowledge (Bruneel et al., 2010). Distrust oriented from different institutional cultures also leads to conflicting attitudes towards the management of collaboration (Davenport et al., 1998) and may negatively influence the collaboration outcome.

There are several ways to overcome the barrier and facilitate the success of UIC. Choosing the appropriate university is essential for successful collaboration (Rajalo \& Vadi, 2017), and firms may choose universities with a similar culture to collaborate. Intermediary organizations like Collaborative Research Centers could facilitate UIC (Villani et al., 2017). This kind of organization acts as a broker to find suitable partners and help with communication to mitigate concerns of UIC such as cultural differences. Flexibility and transparency of university IP policies, as well as shared governance by collaboration partners, also result in trust formation of alliances (Bstieler et al., 2015), which could solve the issue oriented from different institutional cultures.

In summary, we argue that firms could control the negative effect of UIC through the abovementioned strategies. Given the substantial benefits of UIC, the relationship between UIC and firm innovation is likely to be positive. Thus, we posit the following:

Hypothesis 1 UIC is positively related to the focal firm's innovation performance.

\subsection{The moderating role of direct ties}

In the previous section, we hypothesized that UIC has a positive effect on firm innovation performance. However, the interfirm alliance is also an effective path of knowledge searching. It allows the focal firm to be accessible to more knowledge by spanning alliances with other firms (Coleman, 1990). Specifically, direct alliances with other firms promote knowledge sharing, such that relevant knowledge of partners is available to the focal firm from their cooperation on research (Berg et al., 1982). Therefore, the focal firm would potentially acquire valuable knowledge from interfirm collaboration. Additionally, cooperation brings together complementary skills from partners (Kreiser, 2011). The focal firm could learn the set of skills from the development ability of the alters (Ahuja, 2000). Therefore, a firm with more direct ties allows access to broader knowledge resources and it contributes to the recombination towards better innovation.

However, when considering the contingencies of direct ties, we posit that it negatively influences the impact of UIC on innovation because of the diseconomies of scale. As the number of interorganizational collaborations increases, the focal firm is subject to the problem of information overload (Gulati et al., 2012), forcing the focal firm to spend more energy and time to manage and monitor its partners (Guan \& Liu, 2016). Although a firm hopes to benefit from more partners, its absorptive capacity, i.e. the ability to recognize the value of external information and assimilate it (Cohen \& Levinthal, 1990), is limited. As Wu (2013) claims, capabilities such as managerial attention and product development teams are constrained and the use of the capabilities in one setting hinders the use in other 
activities. Hence, more alliances with firms would distract the focal firm from collaboration with universities, thus decreasing the use of absorptive capacity on knowledge and information from universities and the corresponding innovation performance. As a result, diseconomies of scale oriented from alliances with firms distract the focal firm from UIC and it reduces the efficiency of UIC. On the contrary, if the focal firm has fewer alliances with firms, it would have more capabilities on UIC. Thus, the focal firm has more energy and time to focus on UIC and better utilize resources from universities.

Taken together, we argue that when the focal firm has more alliances with firms, the effect of UIC on firm innovation performance is less positive. Given these arguments, we predict:

Hypothesis 2 Direct ties with firms negatively moderate the positive relationship between UIC and the focal firm's innovation performance.

\subsection{The moderating role of technological diversity}

Hypothesis 3 focuses on the influence of technological diversity on the relationship between UIC and firm innovation. Technological diversity refers to the range of the diversification of a firm's technology base (Breschi et al., 2003; Gambardella \& Torrisi, 1998), and it is beneficial to the focal firm's innovation performance because diversity promotes knowledge recombination. Technological diversity may also be detrimental to firm innovation performance when considering coordination costs and strategic ambiguity (Chen et al., 2018; Huang \& Chen, 2010).

Despite the mixed evidence of technological diversity on innovation performance, the focal firm that diversifies its technology could receive more spillover from related technological fields (Garcia-Vega, 2006). Diversity offers the experience to deal with new research areas, and this kind of experience may further accelerate knowledge acquiring from other fields. As mentioned earlier, academic research focuses more on fundamental research, which is different from research conducted by firms. Therefore, if the focal firm has higher technological diversity, the accumulation of capabilities in numerous technological fields allows the focal firm to monitor and absorb new knowledge (Bolli et al., 2020), thereby benefiting more from collaboration with universities.

Hence, if the technological diversity of the focal firm is high, the focal firm has higher absorptive capability, promoting knowledge assimilation from universities and thus increasing the likelihood of innovation. By contrast, if the focal firm does not diversify its technology base, there may be an inadequate experience of the focal firm in the research of other fields, and it may hinder knowledge absorbing from UIC. In this situation, UIC offers less contribution to the focal firm's innovation performance. These arguments lead to the following prediction:

Hypothesis 3 Technological diversity of the focal firm enhances the positive relationship between UIC and the focal firm's innovation performance. 


\section{Methods}

\subsection{Data and sample}

We tested our hypotheses based on data from the pharmaceutical industry (SICs through 2833 to 2836). We chose this industry mainly for two reasons. First, as a knowledge-intensive industry with uncertainty and knowledge complexity, it is ubiquitous for firms in the pharmaceutical industry to acquire knowledge from external sources (Powell et al., 1996). Second, firms in the pharmaceutical industry patent most of their innovations (Paruchuri, 2010), such that we can measure innovation based on patent data.

Our collaboration data was collected from the SDC Platinum database. We selected all firms in the global pharmaceutical industry collaborating with firms as well as universities announced from 1985 to 2014 . We began in 1985 because there were scarce alliances before 1985. We stopped in 2014 to leave at least a five-year window for the measurement of fiveyear forward citations of patents. We used all types of alliances of UIC as well as alliances between firms, including joint venture, equity alliance, and non-equity alliance, for the reason that collaboration scope is always understated and firms could gain access to knowledge from any type of alliances (Schilling \& Phelps, 2007).

Since UIC is relatively scarce compared to collaboration between firms, and our research is based on the alliance of the focal firm both with firms and with universities, we followed previous research defining alliance boundary based on the following rules: each pharmaceutical firm must have a partner also in the pharmaceutical industry (Østergaard et al., 2011) and their alliance must be in the pharmaceutical domain (Schilling \& Phelps, 2007). Similarly, UIC must be in the pharmaceutical domain as well. After that, we searched for joint ventures, subsidiaries, spinoffs (50\% or more ownership), and business units, and attributed them to the ultimate parent firm and considered name changes, mergers and acquisitions (M\&As), and reorganizations, based on the SDC Alliance Database (Kumar \& Zaheer, 2019).

We measured the duration of alliances by adopting a commonly used five-year rolling window approach (Guan \& Liu, 2016) on alliances between firms as well as UIC. This approach assumes that each alliance would last for five years since announced. Based on the alliance duration data, we further listed the dyadic alliance ties of each year for related measures of UIC and the interfirm alliance network. Each node in the alliance network represents a firm and an edge between two nodes represents the alliance between these two firms. Finally, our data contains 285 firms and 96 universities. There are 845 observations of alliances between firms and 204 observations of UIC.

We measured innovation based on patent data because patents are credible indicators of innovation (Trajtenberg, 1987). We collected patent data mainly from the Derwent Innovation Index database, containing patent information from more than forty patent offices, including USPTO, EPO, JPO, SIPO. It covers patent information of more than one hundred countries. Our final sample contains an unbalanced panel with 285 firms and 5076 firm-year observations, which is close to reality and is preferred for avoiding survivorship bias (Baum, 2006).

\subsection{Measures}

\subsubsection{Dependent variable}

Patent citation count We measured the focal firm's innovation performance in year $\mathrm{t}$ as the 5 -year forward citations excluding self-citations of the granted patent $\mathrm{p}$ applied in year $\mathrm{t}$ as: 


$$
\sum_{i=1}^{p}\left(\text { Citation }_{i}+1\right)
$$

where i represents ith patent in year t. Instead of directly using the total number of patent citation count, we painstakingly calculated patent citation count as citations within five years since the patent was published, to make sure that each patent is in the same citation window (Fischer \& Leidinger, 2014).

\subsubsection{Independent variable}

UIC We used the number of universities to which the focal firm is directly connected in year $t$ to measure UIC of the focal firm.

\subsubsection{Control variables}

Direct ties $(\log )$ We calculated direct ties as the number of firms in the alliance network that are directly connected to the focal firm at year $\mathrm{t}$. We added one to this variable and took the logarithm form of it.

Technological diversity We calculated the Blau Index of diversity to control for the technological range of the focal firm as:

$$
1-\sum_{j} p p_{j}^{2}
$$

where $\mathrm{j}$ represents patent class and $p p_{j}$ is the proportion of patents in class $\mathrm{j}$ of the focal firm. It is assigned to 0 if the focal firm did not patent until year t. Higher Blau Index indicates a higher level of heterogeneity.

Indirect ties (log) We controlled for the number of firms that are indirectly connected to the focal firm at year $t$ to capture informal knowledge sharing through the alliance network (Ahuja, 2000). Here indirect ties between two firms imply several connected edges are serving as a path to connect these two firms that are not directly connected. Similar to Direct Ties ( $\log$ ), we logged it by adding one before the transformation.

Structural holes We controlled for structural holes of the focal firm, given that the innovative benefits from spanning structural holes might be correlated with the advantages of knowledge exchange from direct ties (Ahuja, 2000). Structural holes were calculated in three steps. First, dyadic constraint was calculated using Burt's (1992) formula:

$$
c_{i q t}=\left(p_{i q t}+\sum p_{i k t} p_{k q t}\right)^{2}, k \neq i, q
$$

where $p_{i q t}$ represents the proportion of focal firm i's involvement with firm $\mathrm{q}$ in time $\mathrm{t}$ and $p_{i k t} p_{k q t}$ measures the aggregate indirect tie strength between firms $\mathrm{i}$ and $\mathrm{q}$ via firm $\mathrm{k}$ in year t. Then we calculated the total constraint of firm i as $C_{i t}=\sum_{q} c_{i q t}$. Finally following Zaheer and Bell (2005), structural holes of firm i in year t were $1-C_{i t}$.

Technological base ( $\log$ ) We measured technological base as the logged cumulative patent counts until year $\mathrm{t}$, with 0 replaced by a small number of 0.0001 before transformation (Funk, 2014), to capture the absorptive capacity and aggregate R\&D of the focal firm. A model with an annual discounted rate of $15 \%$ was applied (Hall et al., 2005) to calculate technological base: 


$$
\sum_{\alpha=1}^{t}(1-15 \%)^{t-\alpha} P N_{i \alpha}
$$

where $P N_{i \alpha}$ is the number of patents of the focal firm i at year $\alpha$.

Network density We calculated network density as:

$$
\frac{T N_{t}}{n_{t}\left(n_{t}-1\right) / 2}
$$

where $T N_{t}$ represents the total number of connections at year t. $n_{t}$ is the number of nodes. $n_{t}\left(n_{t}-1\right) / 2$ is the potential maximum number of connections in the alliance network of year t.

Average network distance We controlled for average network distance as the mean distance between the focal firm and other firms that could be connected to the focal firm in the alliance network. The distance between two firms is the number of edges of the shortest path that they could be connected and each edge represents an alliance.

Industry distance We measured industry distance between the focal firm and its direct ties as the proportion of cooperation firms that were not in the same four-digit SIC codes as the focal firm at year $t$ to capture the dissimilarity between them.

Country distance with firms International cooperation provides access to diverse knowledge (Rosenkopf \& Almeida, 2003), but it brings more communication and coordination problems than domestic cooperation, hindering interorganization learning (Lyles \& Salk, 1996). We calculated country distance with firms as the proportion of its cooperative firms that were not in the same country as the focal firm in year $\mathrm{t}$.

Country distance with universities Similar to Country Distance with Firms, we controlled for country distance with universities of the focal firm as the proportion of its cooperative universities that were not in the same country as the focal firm in year $\mathrm{t}$.

Indirect ties through universities We measured indirect ties through universities as the set of firms that collaborated with at least one of the collaborating universities of the focal firm at year $t$, to capture the informal knowledge sharing through universities.

Private university percentage We calculated private university percentage as the proportion of collaborating universities of the focal firm which are private universities rather than public ones to control for the influence of university type. Private and public universities have some differences such as sources of funds and sizes, and they may influence UIC.

\subsection{Model estimation}

We used the unconditional fixed-effects Poisson (quasi-maximum likelihood) model to test our hypothesis. This is because our dependent variable, Patent citation count, is nonnegative and takes only integer values. $7 \%$ of the dependent variable is zero, such that we cannot $\log$ transform it. In addition, adding a small positive number $\Delta$ before log transformation result in the expected value of $E[\ln (\Delta+y \mid x)]$, and it cannot be transformed back to our interest $E[y \mid x]$. However, unconditional fixed-effects Poisson quasi-maximum likelihood estimator takes the form $y_{i t}=\alpha_{i} e^{x_{i t}^{\prime} \beta}+\varepsilon_{i t}$ and the conditional mean of the model is

$$
E\left[y_{i t} \mid x_{i t}, \alpha_{i}\right]=\alpha_{i} e^{x_{i t}^{\prime} \beta}=e^{\left(\ln \alpha_{i}+x_{i t}^{\prime} \beta\right)}, \quad \mathrm{t}=1,2, \ldots, \mathrm{T}, \mathrm{i}=1,2, \ldots, \mathrm{N},
$$

where $y_{i t}$ is the patent citation count of firm $\mathrm{i}$ in year $\mathrm{t}, \boldsymbol{x}_{i t}$ includes the independent variable, control variables, and time effects, $\beta$ is the coefficient estimator, $\alpha_{i}$ is a firm-specific 
unobserved time-constant effect, $\varepsilon_{i t}$ is the random error term, and $e$ is the base of natural Logarithms. Using this model, we can capture our interest in Patent citation count. Following Phelps (2010), we included time effects to control for period influences, such as differences oriented from macroeconomic conditions and industry technological opportunity.

\section{Results}

Table 1 presents descriptive statistics and correlations. We checked for multicollinearity through Variance Inflation Factor (VIF) and the highest VIF of variables in our model is 4.59, far below 10, indicating there is not an issue of multicollinearity. As shown in Table 1, the range of Patent Citation Count is from 0 to 4147, and its mean value is 165.77. The mean value of UIC is 0.08 , and the maximum of it is 5 . Consistent with the expectation, UIC is positively correlated with Patent Citation Count $(p<0.05)$.

Tables 2 and 3 present our regression results of the unconditional fixed-effects Poisson model. Model 1 in Table 2 is the baseline model only containing control variables. Model 2 in Table 2 includes the independent variable, UIC. Direct Ties (log) and Technological Diversity are included in Model 3 of Table 2. The interaction term of UIC and Direct Ties $(\log )$ is added in Model 4 of Table 3 and the interaction between UIC and Technological Diversity is included in Model 5 of Table 3. Model 6 in Table 3 is our full model with all variables and interactions included.

Consistent with most previous studies, we find that the focal firm has better innovation performance as the number of cooperative firms increases. The coefficient of Direct Ties $(\log )$ is positive and significant $(p<0.01)$ through Model 3 to Model 6. The negative and significant coefficient $(p<0.01)$ of Technological Diversity suggests that the focal firm may not benefit from diversified research scope. This is convincing because of the mixed evidence of technological diversity on innovation. Additionally, the coefficient of Structural Holes is positive through Model 1 to Model $6(p<0.01)$, which is coherent with prior research indicating that firm innovation increases as it spans structural holes. The coefficients for Technological Base (log) and Average Network Distance are positive and significant $(p<0.01)$. These results indicate that more technology stock and a larger average distance between firms in the alliance network increase the focal firm's innovation performance. The positive relationship between Average Network Distance and Patent Citation Count may be due to the reason that a large average distance results in greater differences of partners in the alliance network, and it may contribute to innovation. In addition, there is a negative relationship between Network Density and Patent Citation Count $(p<0.01)$, indicating that as the number of connections in the alliance network increases, the focal firm performs worse on innovation. Homogenization of densely connected partners may hinder innovation. The negative effect of Country Distance with Universities $(p<0.01)$ implies that international UIC is not as helpful as domestic UIC to improve the focal firm's innovation performance. Moreover, there is no significant effect of Indirect Ties (log) (except in Model 1 and Model 2), Industry Distance with Firms (though marginally in Model 3 to Model 6), Country Distance with Firms, Indirect Ties through Universities (except in Model 1), or Private University Percentage on Patent Citation Count.

Hypothesis 1 states that UIC positively influences the focal firm's innovation performance. As expected, the coefficient of UIC is positive and significant in Model 2 and Model 3 ( $p<0.01$ ), supporting Hypothesis 1 . In addition, the coefficient of UIC is also positively significant in Model $4(p<0.01)$ and Model $6(p<0.1)$. A firm has better innovation performance as the number of UIC increases. 


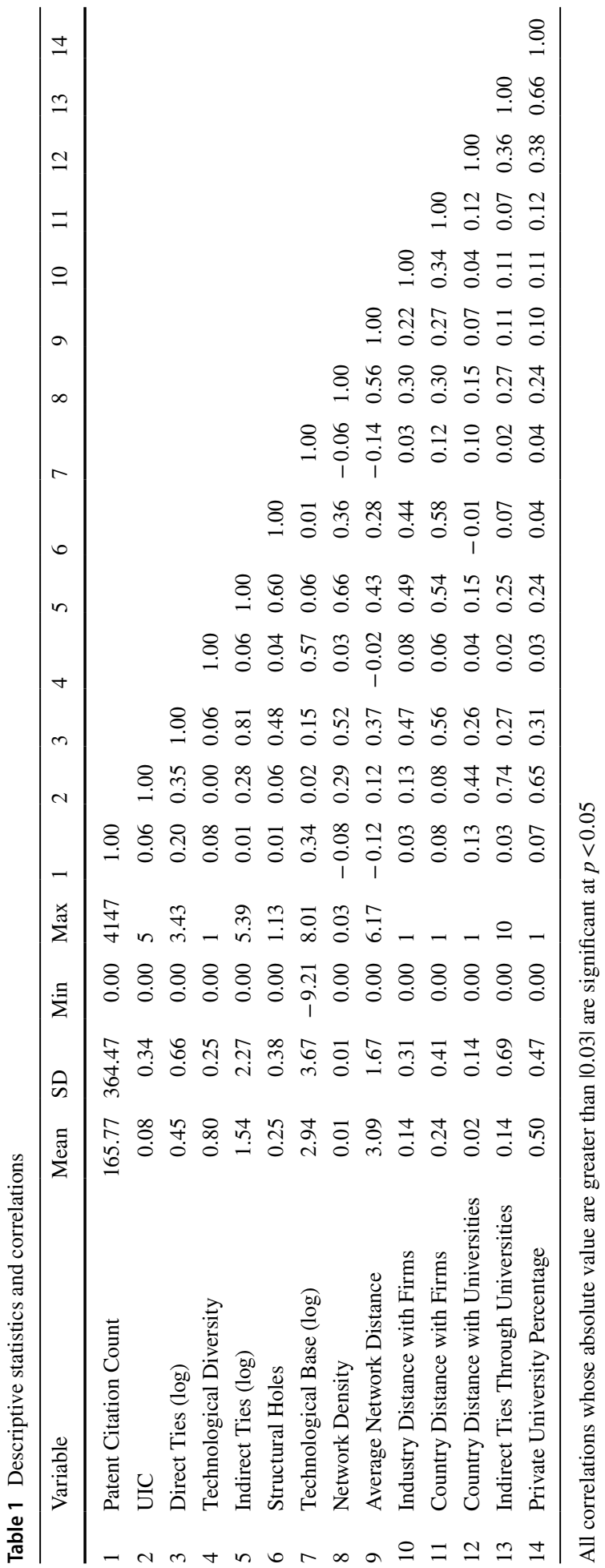


Table 2 Estimation of patent citation count without interaction term

\begin{tabular}{|c|c|c|c|}
\hline \multirow[t]{2}{*}{ Variables } & \multicolumn{3}{|c|}{ Unconditional fixed-effects Poisson model } \\
\hline & Model 1 & Model 2 & Model 3 \\
\hline \multicolumn{4}{|l|}{ Controls } \\
\hline Indirect ties $(\log )$ & $\begin{array}{l}0.0345^{* * *} \\
(0.0082)\end{array}$ & $\begin{array}{l}0.0321 * * * \\
(0.0083)\end{array}$ & $\begin{array}{l}-0.0009 \\
(0.0104)\end{array}$ \\
\hline Structural holes & $\begin{array}{l}0.1972 * * * \\
(0.0355)\end{array}$ & $\begin{array}{l}0.2048^{* * * *} \\
(0.0354)\end{array}$ & $\begin{array}{l}0.2052 * * * \\
(0.0352)\end{array}$ \\
\hline Technological base $(\log )$ & $\begin{array}{l}0.1809^{* * *} \\
(0.0125)\end{array}$ & $\begin{array}{l}0.1807 * * * \\
(0.0125)\end{array}$ & $\begin{array}{l}0.1839^{* * * *} \\
(0.0126)\end{array}$ \\
\hline Network density & $\begin{array}{l}-661.8000 * * * \\
(126.8000)\end{array}$ & $\begin{array}{l}-658.9000^{* * * *} \\
(126.6000)\end{array}$ & $\begin{array}{l}-660.0000^{* * * *} \\
(125.5000)\end{array}$ \\
\hline Average network distance & $\begin{array}{l}0.5679 * * * \\
(0.1093)\end{array}$ & $\begin{array}{l}0.5639 * * * \\
(0.1092)\end{array}$ & $\begin{array}{l}0.5582 * * * \\
(0.1082)\end{array}$ \\
\hline Industry distance with firms & $\begin{array}{l}-0.0174 \\
(0.0418)\end{array}$ & $\begin{array}{l}-0.0354 \\
(0.0419)\end{array}$ & $\begin{array}{l}-0.0775^{*} \\
(0.0431)\end{array}$ \\
\hline Country distance with firms & $\begin{array}{l}-0.0072 \\
(0.0354)\end{array}$ & $\begin{array}{l}0.0054 \\
(0.0355)\end{array}$ & $\begin{array}{l}-0.0258 \\
(0.0358)\end{array}$ \\
\hline Country distance with universities & $\begin{array}{l}-0.1627 \text { *** } \\
(0.0610)\end{array}$ & $\begin{array}{l}-0.2472 * * * \\
(0.0627)\end{array}$ & $\begin{array}{l}-0.2825 * * * \\
(0.0629)\end{array}$ \\
\hline Indirect ties through universities & $\begin{array}{l}0.0193 \\
(0.0237)\end{array}$ & $\begin{array}{l}-0.0318 \\
(0.0260)\end{array}$ & $\begin{array}{l}-0.0054 \\
(0.0262)\end{array}$ \\
\hline Private university percentage & $\begin{array}{l}0.1664 * * \\
(0.0711)\end{array}$ & $\begin{array}{l}0.0910 \\
(0.0718)\end{array}$ & $\begin{array}{l}0.0430 \\
(0.0721)\end{array}$ \\
\hline \multicolumn{4}{|l|}{ Independent } \\
\hline Direct ties $(\log )$ & & & $\begin{array}{l}0.1358 * * * \\
(0.0281)\end{array}$ \\
\hline Technological diversity & & & $\begin{array}{l}-0.2614 * * * \\
(0.0858)\end{array}$ \\
\hline UIC & & $0.2179 * * *$ & $\begin{array}{l}0.1503 * * * \\
(0.0440)\end{array}$ \\
\hline \multicolumn{4}{|l|}{ UIC* direct ties $(\log )$} \\
\hline \multicolumn{4}{|l|}{ UIC $*$ technological diversity } \\
\hline Intercept & $\begin{array}{l}5.2370 * * * \\
(0.1199)\end{array}$ & $\begin{array}{l}5.2430 * * * \\
(0.1198)\end{array}$ & $\begin{array}{l}5.4480 * * * \\
(0.1348)\end{array}$ \\
\hline Firm fixed effects & Yes & Yes & Yes \\
\hline Year fixed effects & Yes & Yes & Yes \\
\hline Firm-years (NT) & 5076 & 5076 & 5076 \\
\hline Firms $(\mathrm{N})$ & 285 & 285 & 285 \\
\hline Log likelihood test & & $1778.32 * * *$ & $4071.61 * * *$ \\
\hline
\end{tabular}

${ }^{*} p<0.1, * * p<0.05, * * * p<0.01$ 
Table 3 Estimation of patent citation count with interaction terms

\begin{tabular}{|c|c|c|c|}
\hline \multirow[t]{2}{*}{ Variables } & \multicolumn{3}{|c|}{ Unconditional fixed-effects Poisson model } \\
\hline & Model 4 & Model 5 & Model 6 \\
\hline \multicolumn{4}{|l|}{ Controls } \\
\hline Indirect ties $(\log )$ & $\begin{array}{l}-0.0052 \\
(0.0106)\end{array}$ & $\begin{array}{l}-0.0009 \\
(0.0104)\end{array}$ & $\begin{array}{l}-0.0052 \\
(0.0105)\end{array}$ \\
\hline Structural holes & $\begin{array}{l}0.1984 * * * \\
(0.0353)\end{array}$ & $\begin{array}{l}0.2053 * * * \\
(0.0351)\end{array}$ & $\begin{array}{l}0.1982 * * * \\
(0.0352)\end{array}$ \\
\hline Technological base $(\log )$ & $\begin{array}{l}0.1833 * * * \\
(0.0126)\end{array}$ & $\begin{array}{l}0.1874 * * * \\
(0.0126)\end{array}$ & $\begin{array}{l}0.1868 * * * \\
(0.0126)\end{array}$ \\
\hline Network density & $\begin{array}{l}-658.6364 * * * \\
(125.4388)\end{array}$ & $\begin{array}{l}-659.8000 * * * \\
(125.3000)\end{array}$ & $\begin{array}{l}-658.4000 \text { *** } \\
(125.2000)\end{array}$ \\
\hline Average network distance & $\begin{array}{l}0.5528 * * * \\
(0.1082)\end{array}$ & $\begin{array}{l}0.5556^{* * *} \\
(0.1080)\end{array}$ & $\begin{array}{l}0.5498 * * * \\
(0.1080)\end{array}$ \\
\hline Industry distance with firms & $\begin{array}{l}-0.0833^{*} \\
(0.0431)\end{array}$ & $\begin{array}{l}-0.0756^{*} \\
(0.0430)\end{array}$ & $\begin{array}{l}-0.0818^{*} \\
(0.0431)\end{array}$ \\
\hline Country distance with firms & $\begin{array}{l}-0.0269 \\
(0.0358)\end{array}$ & $\begin{array}{l}-0.0254 \\
(0.0358)\end{array}$ & $\begin{array}{l}-0.0266 \\
(0.0358)\end{array}$ \\
\hline Country distance with universities & $\begin{array}{l}-0.3034 * * * \\
(0.0632)\end{array}$ & $\begin{array}{l}-0.3248 * * * \\
(0.0632)\end{array}$ & $\begin{array}{l}-0.3481^{* * * *} \\
(0.0635)\end{array}$ \\
\hline Indirect ties through universities & $\begin{array}{l}-0.0303 \\
(0.0283)\end{array}$ & $\begin{array}{l}-0.0203 \\
(0.0263)\end{array}$ & $\begin{array}{l}-0.0471^{*} \\
(0.0286)\end{array}$ \\
\hline Private university percentage & $\begin{array}{l}0.0793 \\
(0.0732)\end{array}$ & $\begin{array}{l}0.0052 \\
(0.0722)\end{array}$ & $\begin{array}{l}0.0420 \\
(0.0732)\end{array}$ \\
\hline \multicolumn{4}{|l|}{ Independent } \\
\hline Direct ties $(\log )$ & $\begin{array}{l}0.1549 * * * \\
(0.0292)\end{array}$ & $\begin{array}{l}0.1322 * * * \\
(0.0280)\end{array}$ & $\begin{array}{l}0.1522 * * * \\
(0.0292)\end{array}$ \\
\hline Technological diversity & $\begin{array}{l}-0.2568 * * * \\
(0.0857)\end{array}$ & $\begin{array}{l}-0.3876^{* * * *} \\
(0.0913)\end{array}$ & $\begin{array}{l}-0.3840 * * * \\
(0.0912)\end{array}$ \\
\hline UIC & $\begin{array}{l}0.3676^{* * * *} \\
(0.1032)\end{array}$ & $\begin{array}{l}-0.0232 \\
(0.0668)\end{array}$ & $\begin{array}{l}0.1979 * \\
(0.1128)\end{array}$ \\
\hline UIC* direct ties $(\log )$ & $\begin{array}{l}-0.0796 * * \\
(0.0344)\end{array}$ & & $\begin{array}{l}-0.0823^{* *} \\
(0.0339)\end{array}$ \\
\hline UIC $*$ technological diversity & & $\begin{array}{l}0.3027 * * * \\
(0.0787)\end{array}$ & $\begin{array}{l}0.3109 * * * \\
(0.0795)\end{array}$ \\
\hline \multicolumn{4}{|l|}{ Other } \\
\hline Intercept & $\begin{array}{l}5.4433 * * * \\
(0.1347)\end{array}$ & $\begin{array}{l}5.5490 * * * \\
(0.1367)\end{array}$ & $\begin{array}{l}5.5450 * * * \\
(0.1365)\end{array}$ \\
\hline Firm fixed effects & Yes & Yes & Yes \\
\hline Year fixed effects & Yes & Yes & Yes \\
\hline Firm-years (NT) & 5076 & 5076 & 5076 \\
\hline Firms $(\mathrm{N})$ & 285 & 285 & 285 \\
\hline Log likelihood test & $4441.11 * * *$ & $5167.72 * * *$ & $5573.15 * * *$ \\
\hline
\end{tabular}

${ }^{*} p<0.1, * * p<0.05, * * * p<0.01$ 
Hypothesis 2 proposes a negative moderating effect of direct ties on the relationship between UIC and firm innovation performance. In line with Hypothesis 2, the interaction between UIC and Direct Ties (log) is negatively related to Patent Citation Count in Model 4 and Model 6 ( $p<0.05)$. We plot this interaction in the first graph of Fig. 1. As can be seen, this graph shows that the positive effect of UIC on predicted Patent Citation Count is less positive when the focal firm has more direct ties. The results largely support Hypothesis 2.

Hypothesis 3 states that technological diversity positively moderates the relationship between UIC and firm innovation performance. The interaction between UIC and Technological Diversity is positively significant in Model 5 and Model $6(p<0.01)$. We plot this interaction in the second picture of Fig. 1. The effect of UIC on predicted Patent Citation Count becomes more positive as the focal firm has higher technological diversity, thus providing support for Hypothesis 3.
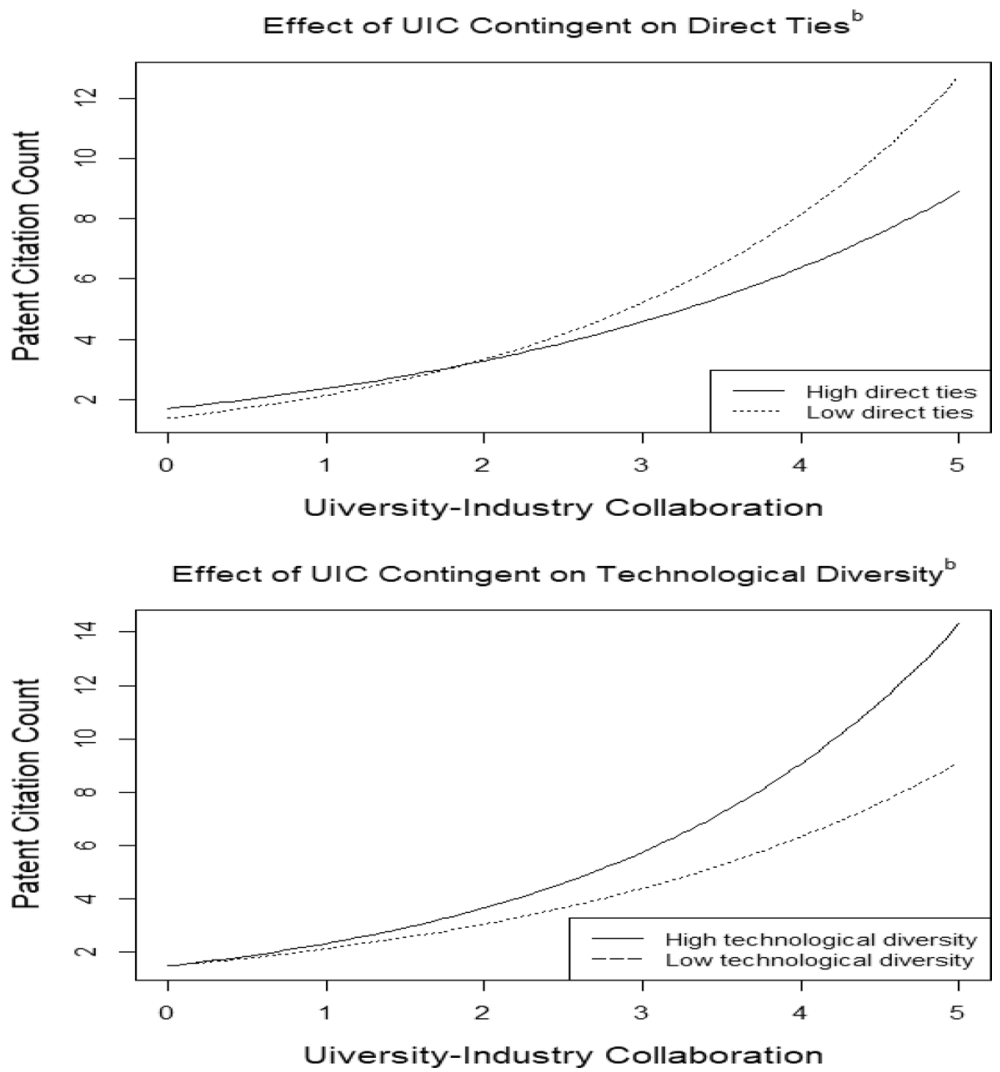

Fig. 1 Predicted Values ${ }^{\mathrm{a}}$ of Patent Citation Count. ${ }^{\mathrm{a}}$ All calculations are based on Model 6, holding all other

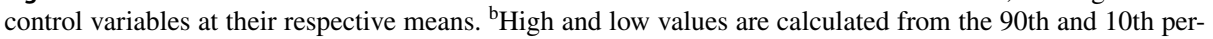
centiles of Direct Ties and Technological Diversity, respectively 


\section{Discussion}

How does UIC affect firm innovation? Scholars have long emphasized knowledge spillovers through interorganizational collaboration. However, the stream of research investigating the impact of it on firm innovation mainly focuses on collaboration between firms. Few existing studies of UIC on firm innovation failed to take interfirm alliances into account, and it may cause estimation bias. In this study, we explore the relationship between UIC and firm innovation performance with the consideration of the interfirm alliance network and study contingencies that may influence the relationship.

Specifically, we find that UIC is beneficial to the focal firm's innovation performance and the benefit is likely to be weakened if the firm spans its alliances with other firms. This result highlights the negative interaction between two kinds of collaboration. More alliances with firms may reduce the positive influence of collaborating with universities. This is because of the limited absorptive ability of a firm, resulting in diseconomies of scale. More alliances with firms bring the problem of information overload, distracting the focal firm from UIC and thus decreasing its ability to acquire knowledge from universities.

Additionally, our results indicate that technological diversity of the focal firm positively moderates the relationship between UIC and firm innovation performance. A firm may acquire related experience and skill by exploring different fields, thus increasing its absorptive capacity to assimilate knowledge from universities. On the contrary, if a firm concentrates its technology, it would be harder for it to receive information from other fields and thus benefit less from collaborating with universities.

Our study has important implications for research and practice. First, we contribute to the literature of UIC by including the alliance network of firms to study how UIC influences firm innovation. Existing studies have explored the influence of UIC on firm innovation performance (Baba et al., 2009; Biedenbach et al., 2018; Kobarg et al., 2018), and propose a performance measurement system to evaluate UIC theoretically (Al-Ashaab et al., 2011; Perkmann et al., 2011). However, existing research failed to take the interfirm alliance network into account, and it may cause bias of estimation. Consequently, we explore the effect of UIC on firm innovation by controlling for the interfirm alliance network.

Second, we contribute to the interorganizational relationship literature by studying the interaction of UIC and interfirm alliances on firm innovation. In addition to UIC, the influence of interfirm alliances on firm innovation has been largely examined (Ahuja, 2000; Dyer \& Nobeoka, 2000; Hargadon \& Sutton, 1997; Kumar \& Zaheer, 2019; McEvily \& Zaheer, 1999; Phelps, 2010; Schilling \& Phelps, 2007). What remained unclear is how the interaction between UIC and interfirm alliance impacts firm innovation. We fill in the gap by examining the moderating role of direct ties on the impact of UIC on firm innovation.

Finally, this paper has managerial implications. We find that collaboration with firms might be detrimental to the effect of UIC. Therefore, firms should consider collaboration with firms and universities simultaneously and combine these two kinds of alliances strategically. A firm has restricted resources, such as employees and funding, implying a firm only has limited capacity for collaboration. Hence, a firm should consider alliance combination between firms and universities, to acquire knowledge efficiently to increase innovation performance. Additionally, our results indicate that if a firm spans the diversity of its technology base, it may be beneficial to innovation through UIC. Therefore, a firm may consider the possibility to be diversified even if it does not contribute to innovation directly.

Notwithstanding its contributions, this study has several limitations. First, unlike the alliance network structure between firms, we only consider direct ties of UIC. Other 
network attributes, such as structural holes and network closeness of UIC, might provide additional findings. Future research may study the effect of relevant network attributes on firm innovation performance. Additionally, it may be interesting to integrate the interfirm alliance network and the network between universities and firms, to explore the effect of the blended network on firm innovation.

Second, we only include a few variables about cooperative universities of the focal firm. The academic research quality of universities might be a key factor that influences the impact of UIC on firm innovation. Therefore, future research may include academic research quality to further explore factors that may affect innovation. In addition, it is also worthwhile to study the influence of UIC on university innovation, to find out the mechanism behind the commercialization of academic research.

Finally, our empirical context is the biopharmaceutical industry, a high technology industry that relies heavily on R\&D. Future research may test our results in other high technology industries, to find out if our conclusion still holds. Another interesting area of research might be oriented from the view of universities, to study the effect of collaboration between a university and firms from different industries on university research performance. Under this kind of research, one may discover if collaboration with firms improves the research quality of universities and how it works.

Acknowledgements The work in this paper was funded by the National Natural Science Foundation of China (Project Number 71732002).

\section{Declarations}

Conflict of interest The authors declare that they have no conflict of interest.

\section{References}

Ahuja, G. (2000). Collaboration networks, structural holes, and innovation: A longitudinal study. Administrative Science Quarterly, 45(3), 425-455.

Al-Ashaab, A., Flores, M., Doultsinou, A., \& Magyar, A. (2011). A balanced scorecard for measuring the impact of industry-university collaboration. Production Planning \& Control, 22(5-6), 554-570.

Ankrah, S., \& Omar, A. T. (2015). Universities-industry collaboration: A systematic review. Scandinavian Journal of Management, 31(3), 387-408.

Anselin, L., Varga, A., \& Acs, Z. (1997). Local geographic spillovers between university research and high technology innovations. Journal of Urban Economics, 42(3), 422-448.

Arthur, B. (2007). The structure of invention. Research Policy, 36(2), 274-287.

Baba, Y., Shichijo, N., \& Sedita, S. R. (2009). How do collaborations with universities affect firms' innovative performance? The role of 'pasteur scientists' in the advanced materials field. Research Policy, 38(5), 756-764.

Baden-Fuller, C., \& Grant, R. M. (2004). A knowledge accessing theory of strategic alliances. Journal of Management Studies, 41(1), 61-84.

Balachandran, S., \& Hernandez, E. (2018). Networks and innovation: Accounting for structural and institutional sources of recombination in brokerage triads. Organization Science, 29(1), 80-99.

Baum, C. F. (2006). An introduction to modern econometrics using Stata. Stata Press.

Bellini, E., Piroli, G., \& Pennacchio, L. (2019). Collaborative know-how and trust in university-industry collaborations: Empirical evidence from ICT firms. The Journal of Technology Transfer, 44(6), 1939-1963.

Berg, S. V., Duncan, J., \& Friedman, P. (1982). Joint venture strategies and corporate innovation. Oelgeschlager, Gunn \& Hain.

Biedenbach, T., Marell, A., \& Vanyushyn, V. (2018). Industry-university collaboration and absorptive capacity: An empirical study in a Swedish context. International Journal of Technology Management, 76(1-2), 81-103. 
Bolli, T., Seliger, F., \& Woerter, M. (2020). Technological diversity, uncertainty and innovation performance. Applied Economics, 52(17), 1831-1844.

Breschi, S., Lissoni, F., \& Malerba, F. (2003). Knowledge-relatedness in firm technological diversification. Research Policy, 32(1), 69-87.

Bruneel, J., D'Este, P., \& Salter, A. (2010). Investigating the factors that diminish the barriers to university-industry collaboration. Research Policy, 39(7), 858-868.

Bstieler, L., Hemmert, M., \& Barczak, G. (2015). Trust formation in university-industry collaborations in the US biotechnology industry: IP policies, shared governance, and champions. Journal of Product Innovation Management, 32(1), 111-121.

Burt, R. S. (1992). Structural holes: The social structure of competition. Harvard University Press.

Chen, C. J., Lin, B. W., Lin, J. Y., \& Hsiao, Y. C. (2018). Technological diversity, knowledge flow and capacity, and industrial innovation. Technology Analysis \& Strategic Management, 30(12), 1365-1377.

Cohen, W. M., \& Levinthal, D. A. (1990). Absorptive capacity: A new perspective on learning and innovation. Administrative Science Quarterly, 35(1), 128-152.

Coleman, J. S. (1990). Foundations of social theory. Harvard University Press.

Davenport, S., Davies, J., \& Grimes, C. (1998). Collaborative research programmes: Building trust from difference. Technovation, 19(1), 31-40.

Demirkan, I., \& Demirkan, S. (2012). Network characteristics and patenting in biotechnology, 19902006. Journal of Management, 38(6), 460-461.

Dyer, J. H., \& Nobeoka, K. (2000). Creating and managing a high-performance knowledge-sharing network: The Toyota case. Strategic Management Journal, 21(3), 345-367.

Fischer, T., \& Leidinger, J. (2014). Testing patent value indicators on directly observed patent valueAn empirical analysis of Ocean Tomo patent auctions. Research Policy, 43(3), 519-529.

Fleming, L. (2001). Recombinant uncertainty in technological search. Management Science, 47(1), $117-132$.

Funk, R. J. (2014). Making the most of where you are: Geography, networks, and innovation in organizations. Academy of Management Journal, 57(1), 193-222.

Gambardella, A., \& Torrisi, S. (1998). Does technological convergence imply convergence in markets? Evidence from the electronics industry. Research Policy, 27(5), 445-463.

Garcia-Vega, M. (2006). Does technological diversification promote innovation? An empirical analysis for European firms. Research Policy, 35(2), 230-246.

Gassol, J. H. (2007). The effect of university culture and stakeholders' perceptions on university-business linking activities. The Journal of Technology Transfer, 32(5), 489-507.

Guan, J., \& Liu, N. (2016). Exploitative and exploratory innovations in knowledge network and collaboration network: A patent analysis in the technological field of nano-energy. Research Policy, 45(1), 97-112.

Gulati, R., Sytch, M., \& Tatarynowicz, A. (2012). The rise and fall of small worlds: Exploring the dynamics of social structure. Organization Science, 23(2), 449-471.

Hall, B. H., Jaffe, A., \& Trajtenberg, M. (2005). Market value and patent citations. RAND Journal of Economics, 36(1), 16-38.

Hamel, G. (1991). Competition for competence and inter-partner learning within international strategic alliances. Strategic Management Journal, 12(s1), 83-103.

Hargadon, A., \& Sutton, R. I. (1997). Technology brokering and innovation in a product development firm. Administrative Science Quarterly, 42(4), 716-749.

Henderson, R. M., \& Clark, K. B. (1990). Architectural innovation: The reconfiguration of existing product technologies and the failure of established firms. Administrative Science Quarterly, 35(1), 9-30.

Howells, J., Nevada, M., \& Georghiou, L. (1998). Industry-academic links in the UK. A report to the higher education funding councils of England, Scotland and Wales, PREST. University of Manchester.

Huang, Y. F., \& Chen, C. J. (2010). The impact of technological diversity and organizational slack on innovation. Technovation, 30(7-8), 420-428.

Kobarg, S., Stumpf-Wollersheim, J., \& Welpe, I. M. (2018). University-industry collaborations and product innovation performance: The moderating effects of absorptive capacity and innovation competencies. The Journal of Technology Transfer, 43(6), 1696-1724.

Kreiser, P. M. (2011). Entrepreneurial orientation and organizational learning: The impact of network range and network closure. Entrepreneurship Theory and Practice, 35(5), 1025-1050.

Kumar, P., \& Zaheer, A. (2019). Ego-network stability and innovation in alliances. Academy of Management Journal, 62(3), 691-716. 
Lane, P. J., \& Lubatkin, M. (1998). Relative absorptive capacity and interorganizational learning. Strategic Management Journal, 19(5), 461-477.

Lin, N. (1982). Social resources and instrumental action. In P. Marsden \& N. Lin (Eds.), Social structure and network analysis (pp. 131-145). Sage.

Lyles, M. A., \& Salk, J. E. (1996). Knowledge acquisition from foreign parents in international joint ventures: An empirical examination in the Hungarian context. Journal of International Business Studies, 27(5), 877-903.

March, B. W., \& Wesoowski, W. (1986). Social mobility and social structure. Routledge.

McEvily, B., \& Zaheer, A. (1999). Bridging ties: A source of firm heterogeneity in competitive capabilities. Strategic Management Journal, 20(12), 1133-1156.

Merton, R. (1973). The sociology of science: Theoretical and empirical investigations. University of Chicago Press.

Mowery, D. C., Sampat, B. N., \& Ziedonis, A. A. (2002). Learning to patent: Institutional experience, learning, and the characteristics of US university patents after the Bayh-Dole Act, 1981-1992. Management Science, 48(1), 73-89.

Nathan, M. (2015). Same difference? Minority ethnic inventors, diversity and innovation in the UK. Journal of Economic Geography, 15(1), 129-168.

Oliver, C. (1990). Determinants of interorganizational relationships: Integration and future directions. Academy of Management Review, 15(2), 241-265.

Østergaard, C. R., Timmermans, B., \& Kristinsson, K. (2011). Does a different view create something new? The effect of employee diversity on innovation. Research Policy, 40(3), 500-509.

Paruchuri, S. (2010). Intraorganizational networks, interorganizational networks, and the impact of central inventors: A longitudinal study of pharmaceutical firms. Organization Science, 21(1), 63-80.

Perkmann, M., Neely, A., \& Walsh, K. (2011). How should firms evaluate success in university-industry alliances? A performance measurement system. R\&D Management, 41(2), 202-216.

Perkmann, M., \& Walsh, K. (2007). University-industry relationships and open innovation: Towards a research agenda. International Journal of Management Reviews, 9(4), 259-280.

Phelps, C. C. (2010). A longitudinal study of the influence of alliance network structure and composition on firm exploratory innovation. Academy of Management Journal, 53(4), 890-913.

Powell, W. W., Koput, K. W., \& Smith-Doerr, L. (1996). Interorganizational collaboration and the locus of innovation: Networks of learning in biotechnology. Administrative Science Quarterly, 41(1), $116-145$.

Rajalo, S., \& Vadi, M. (2017). University-industry innovation collaboration: Reconceptualization. Technovation, 62, 42-54.

Reagans, R., Zuckerman, E., \& McEvily, B. (2004). How to make the team: Social networks vs. demography as criteria for designing effective teams. Administrative Science Quarterly, 49(1), 101-133.

Rosenberg, N., \& Nelson, R. R. (1994). American universities and technical advance in industry. Research Policy, 23(3), 323-348.

Rosenkopf, L., \& Almeida, P. (2003). Overcoming local search through alliances and mobility. Management Science, 49(6), 751-766.

Schilling, M. A., \& Phelps, C. C. (2007). Interfirm collaboration networks: The impact of large-scale network structure on firm innovation. Management Science, 53(7), 1113-1126.

Smith-Doerr, L., Owen-Smith, J., Koput, K. W., \& Powell, W. W. (1999). Networks and knowledge production: Collaboration and patenting in biotechnology. In R. T. A. J. Leenders \& S. M. Gabbay (Eds.), Corporate social capital and liability. Springer.

Soh, P. H. (2003). The role of networking alliances in information acquisition and its implication for new product performance. Journal of Business Venturing, 18(6), 727-744.

Stuart, T. E. (2000). Interorganizational alliances and the performance of firms: A study of growth and innovation rates in a high-technology industry. Strategic Management Journal, 21(8), 791-811.

Stuart, T. E., Hoang, H., \& Hybels, R. C. (1999). Interorganizational endorsements and the performance of entrepreneurial ventures. Administrative Science Quarterly, 44(2), 315-349.

Suzuki, J., \& Kodama, F. (2004). Technological diversity of persistent innovators in Japan: Two case studies of large Japanese firms. Research Policy, 33(3), 531-549.

Teece, D. J. (1986). Profiting from technological innovation: Implications for integration, collaboration, licensing and public policy. Research Policy, 15(6), 285-305.

Trajtenberg, M. (1987). Patents, citations, and innovations: Tracing the links. Working paper no. 2457, National Bureau of Economic Research. Washington, DC.

Utterback, J. M. (1971). The process of technological innovation within the firm. Academy of Management Journal, 14(1), 75-88. 
Villani, E., Rasmussen, E., \& Grimaldi, R. (2017). How intermediary organizations facilitate universityindustry technology transfer: A proximity approach. Technological Forecasting and Social Change, $114,86-102$.

Wu, B. (2013). Opportunity costs, industry dynamics, and corporate diversification: Evidence from the cardiovascular medical device industry, 1976-2004. Strategic Management Journal, 34(11), 1265-1287.

Zaheer, A., \& Bell, G. G. (2005). Benefiting from network position: Firm capabilities, structural holes, and performance. Strategic Management Journal, 26(9), 809-825.

Publisher's Note Springer Nature remains neutral with regard to jurisdictional claims in published maps and institutional affiliations. 